Amir Kapetanović (Zagreb)

\title{
Languages ANd Their Registers in Medieval Croatian Culture*
}

\section{Introduction}

1.1. The lingua vernacula and other languages. The area between the Drava, the Danube and the Adriatic Sea, where the ancestors of the Croats settled in the early Middle Ages, was located at the intersection of the Latin and Greek cultures. Of the languages spoken in the area, the one that left the most traces in Slavic was the Romance idiom of Dalmatia (known as the Dalmatian or Dalmatic language); its variants existed along the Eastern coast of the Adriatic side by side with Croatian (until the $15^{\text {th }}$ cent. in Dubrovnik, and until as late as the $19^{\text {th }}$ cent. on Krk). A number of Dalmatian words entered the literary texts composed by Croatian writers of the relevant period, e.g. kelomna ('pillar', Nalješković) or močira ('stone wall', Marulić)'.

The Latin tongue established itself among the ancestors of the Croats as the language of liturgy, law, diplomacy and literature. From the late $9^{\text {th }}$ or early $10^{\text {th }}$ cent. onwards, however, it finds itself in competition with literary Church Slavic in the domains of liturgy and literature. Constituting part of the Pax Slavia Latina, the ethnic territory of Croatia saw significant Latin-Slavic bilingualism during the Middle Ages ${ }^{2}$. Next to these two languages, the living Common Slavic speech also existed within the Croatian community, giving rise to all three dialects of Croatian (Čakavian, Štokavian and Kajkavian) towards the end of the $11^{\text {th }}$ cent. Old Croatian, with assorted dialectal characteristics, proved itself worthy of a literary language already in the Middle Ages: Very early on, the lingua vernacula won over its rights, and if we value medieval Croatian literature for its democratic spirit, its popular character, its horizontal orientation, it is primarily due to its language, and only secondarily - or at most in parallel - due to its thematic directions ${ }^{3}$.

\footnotetext{
* The present article was written as part of the project entitled DOCINEC (2698 Documentation and Interpretation of the Earliest Croatian) with financial support from the Croatian Science Foundation (HRZZ).

${ }^{1}$ In the subsequent periods, Croatian was - to a certain degree - influenced by contacts with various other non-Slavic languages (Italian, German, Hungarian, Turkish), depending on region and time. ${ }^{2}$ M. Minaljević, Položaj crkvenoslavenskoga jezika u hrvatskoj srednjovjekovnoj kulturi, [in:] Zbornik na trudovi od Megjunarodniot naučen sober [Ohrid, 4.-7.11.2010], ed. I. VeLEV, A. GirevsKi, L. Makarioska, I. Piperkoski, K. Mokrova, Skopje 2011, p. 229-238.

${ }^{3}$ E. Hercigonja, Srednjovjekovna književnost, Zagreb 1975, p. 30.
} 


\subsection{The Slavic languages in medieval Croatian linguistic culture: diglossia/} triglossia. The interrelations of Church Slavic and Old Croatian were rather dynamic and quite intricate. The Vienna Folia $\left(11^{\text {th }}-12^{\text {th }}\right.$ cent.), a Glagolitic manuscript containing fragments of the Sacramentary, are considered to be the earliest text written in the Croatian recension of Church Slavic ${ }^{4}$. Old Croatian, with an array of dialectal bases, was used in everyday life (in the family, in the company of acquaintances and friends, at work) as well as, undoubtedly, in the unrecorded medieval oral literature ${ }^{5}$. The co-existence of Church Slavic and Old Croatian constituted an instance of diglossia 6 .

From the $14^{\text {th }}$ cent. onwards, the contact between Church Slavic and Old Croatian in the sphere of the literary language led to their blending, giving rise to a third idiom - a hybrid variety of the literary language (Cr. kontaktni/hibridni jezičnoknjiževni varijetet). This language was not subject to a strict norm: the realization of the Church Slavic and Old Croatian components was conditioned by

\footnotetext{
${ }^{4}$ The influence of Croatian on Church Slavic in this text is visible primarily in the area of phonologi-

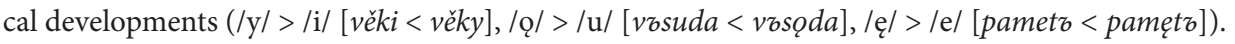

${ }^{5}$ The contemporary conception of medieval Croatian literature, and of language use at that time, is significantly distorted due to its being based solely on currently extant literary texts. The actual complexity of the situation can be gleaned from testimonies like the one in Šžgorićs De situ Illyricae et civitate Sibenici (1487): the work mentions a wide variety of poetic forms completely absent from surviving medieval Croatian poetry (funeral songs, love songs, workers' and shepherds' songs, Christmas songs, dancing songs).

${ }^{6}$ The literature on diglossia is vast (cf., for instance, the survey of literature up to 1990 in: M. FERNÁNDEZ, Diglossia. A Comprehensive Bibliography 1960-1999 and supplements, Amsterdam-Philadelphia 1993). Apart from the classic works by Ferguson (Ch.A. Ferguson, Diglossia, Wo 15, 1959, p. 325340) and Fishman (J.A. Fishman, Bilingualism with and without diglossia, diglossia with and without bilingualism, JSI 23.2, 1993, p. 29-38), it is necessary to take into account certain works dealing with diglossia in the Slavic world, particularly in Rus', e.g. В.А. УСпенский, Диглоссия и двуязычие в истории русского литературного языка, IJSLP 27, 1983, р. 81-126; Г. Хютль-ФольтеР, Диглоссия в Древней Руси, WSJ 24, 1978, p. 108-123; D.S. Wortн, On diglossia in Medieval Russia, WS 23, 1978, p. 371-393; K.-D. Seemann, Die 'Diglossie' und die Systeme der sprachlichen Kommunikation im alten Russland, [in:] Slavistische Studien zum IX. Internationalen Slavistenkongressin Kiev, KölnWien 1983, p. 553-561; G. Thомаs, The Role of Diglossia in the Development of the Slavonic Literary Languages, SR 37, 1989, p. 273-282; И.С. Улуханов, О языке Древней Руси, Москва 1972. For a critique of Uspenskij's theory, cf. М.И. ШАпир, Теория “иерковнославянско-русской диглоссии" и ее сторонники. По поводу книги Б.А. Успенского "История русского титературного языка (XI-XVII в8.)", RLin 13.3, 1989, p. 271-309. For the purposes of the present work, and the study of the linguistic situation in medieval Croatia in general, it is impossible to employ Tolstoj's model of the 'genre pyramid': the latter was designed for the Pax Slavia Orthodoxa and is not suitable for the Pax Slavia Latina. Tolstoj himself addresses the issue as follows: Код Словена који су спадали у други културни ареал Pax Slavia Latina била је другачија културна-књижевна хијерархија (Among those Slavs who belonged to the other cultural area, the Pax Slavia Latina, there existed a different cultural/literary hierarchy). Н.И. Толстой, Однос старог српског књишког језика према старом словенском језику (У вези са развојем жанрова у старој српској кюижевности), NSSVD 8.1, 1982, p. 18.
} 
a number of factors, such as genre, content, aims and target audience. In this way, in the late medieval period, the Church Slavic/Old Croatian diglossia transformed into an instance of triglossia ${ }^{7}$. Accordingly, the new hybrid variety of the literary language occupies a position on par with Church Slavic and Old Croatian as such. In view of these complex and shifting relations among the two or three similar, closely related languages, the attribution of a given text to one of them is bound to pose problems.

1.3. Determining the proportion of each Slavic language. A set of linguistic criteria for the division of texts into Church Slavic and Old Croatian has been proposed by Anica Nazor ${ }^{8}$. We find a description of some of the pivotal linguistic traits in her study on the $15^{\text {th }}$ cent. Ivančić Miscellany. Concluding her investigations, Nazor states:

The linguistic analysis of the Ivančić Miscellany shows that this text cannot be considered as Church Slavic in its entirety, since some of its parts (Treatise on the seven deadly sins, Exodus, Confession) are almost fully based on living speech, while certain others (Contemplation, Words of life [and] salvation, Sermon on love, Explanation of the mass, Words from the teachings of the holy fathers, Questions and answers, Blessing of the table, but also Miracles of Virgin Mary) largely have that basis too. Only one-third of the Ivančić Miscellany comprises texts that retain Church Slavic linguistic traits (two epistles on Saint Jerome, Miracles of Mary Magdalene, the prayers: St. Augustine, St. Mary, Mother of God of Seven Joys, Blessed Bede, St. Thomas, Pope Clement, Blessed Bernard. ${ }^{9}$

Disregarding the fact that some of the criteria established by Nazor could be contested from the standpoint of modern scholarship ${ }^{10}$, her findings remain

\footnotetext{
${ }^{7}$ M. Minaljević, Položaj..., passim.

${ }^{8}$ A. Nazor, Jezični kriteriji pri određivanju donje granice crkvenoslavenskog jezika u hrvatskoglagoljskim tekstovima (Prilog diskusiji o problemima crkvenoslavenskog thesaurusa), Slo 13, 1983, p. 68-86. The consideration of the issue has led to the rise of certain practical questions, e.g. whether all or only some texts from the Glagolitic miscellany should be included in the corpus on which the dictionary of Croatian Church Slavic would be based.

${ }^{9}$ Ibidem, p. 85.

${ }^{10}$ Although Nazor's analysis leads her to the correct conclusions, today we could dispute the validity of some of her criteria. For example, the forms of the Church Slavic conditional mood (bim, biš...) do not diverge from the typical Čakavian paradigm. The reflex $/ e ̨ />/ a /$ is not consistent in the Čakavian dialects, so that its absence (respectively, the reflex /ę/ >/e/) cannot be considered an indicator of a lower share of Čakavian traits. Besides, the dichotomy Church Slavic-Old Croatian does not constitute a relationship literary-colloquial or older-younger (cf., for example, the treatment of texts with $\check{c} z t o$ instead of $\check{c} a$ as older). The basic fallacy in older Croatian philological literature consists in the claim that the Croatian language emerged as a result of long-term influence of the spoken language on Church Slavic (Old Croatian was recognized as a language of literature already in medieval times!) and that Old Croatian developed from Church Slavic. Thus, for example, in the introduction to her work, Nazor writes (A. NAzor, Jezični kriteriji..., p. 68) that Old Croatian and Church Slavic coexisted throughout the entire medieval period and got to intertwine in many texts;
} 
highly valuable. The language of the Glagolitic miscellany cannot be analyzed as a monolith - every text requires a separate investigation: each part of the miscellany is, from the linguistic point of view, a problem in itself, which therefore has to be solved individually ${ }^{11}$.

In recent times, the Slavic idioms of medieval Croatian texts have been studied by Stjepan Damjanović. According to his theory, the basic language of the Baška tablet is Church Slavic, and not Old Croatian, as claimed by virtually all earlier philologists ${ }^{12}$. However, a new study ${ }^{13}$ draws attention to the fact that all analogical epigraphic and legal texts were written in Old Croatian; moreover, most of the linguistic material of the Baška tablet may be analyzed as belonging to both idioms (all the same, the text is too short to warrant a conclusion based on statistics). The concept of a Church Slavicized popular language has also been proposed - an occasional (irregular) blend of two Slavic linguistic systems existing in a state of diglossia. This amalgam is a product of conscious effort: the author introduces Church Slavic elements in order to enable the Old Croatian language to achieve the same level of expressivity that is inherent in donation documents written in Latin and in other legal documents composed in accordance with the ars dictandi $i^{14}$.

1.4. Division of the languages. The distribution of the relevant languages corresponding to the three functional styles was described by Damjanović as follows: Liturgical and legal texts stand on opposite sides as regards the use of Croatian and Croatian Church Slavic. [...] However, there are also belletristic texts among them, their language by no means as predictable and invariant ${ }^{15}$. Developing this position, Mihaljević speaks of two distinct periods. During the first one $\left(11^{\text {th }}-14^{\text {th }}\right.$ cent.), Church Slavic:

nevertheless, further (p. 70) we read that the Church Slavic linguistic core started to erode more and more, to finally transform into a vernacular one. For certain similar positions, cf. the recent survey of Croatian linguistic history: R. KAтіčıć, Hrvatski jezik, Zagreb 2013, p. 47-58.

Conservative writers retained a larger proportion of Church Slavic elements, especially in those texts that were more related closely to Church matters or those which they wished to make more elegant in style. Even this, however, cannot be the basis for an a priori conclusion that the texts in question must be old. Besides, in the work under discussion, Nazor only uses her criteria to classify texts as Church Slavic or vernacular; the notion of the 'hybrid language' had not yet entered scholarly debate at the time when the study was written.

${ }^{11}$ A. Nazor, Jezični kriteriji..., p. 69.

${ }^{12}$ S. Damjanović, Jezik hrvatskih glagoljaša, Zagreb 2008.

${ }^{13}$ A. Kapetanović, Reflections of Church Slavonic-Croatian diglossia on the Baška tablet: a new contribution concerning its language and linguistic layers, ZSl 60.3, 2015, p. 335-365.

${ }^{14}$ E.R. CurTius, Evropska književnost i latinsko srednjovjekovlje, trans. S. Markuš, ed. T. LADAN, Zagreb 1971; J. StıPIšıć, Pomoćne povijesne znanosti u teoriji i praksi, Zagreb 1972; A. Stamać, 'Baščanska ploča' kao književno djelo, Cro 26/28, 1987, p. 17-27.

${ }^{15}$ S. Damjanović, Jezik..., p. 36. 
played the role of the literary language. This was the language in which both liturgical and non-liturgical literary works were written, which, unfortunately, only survive in fragments [...] The colloquial Croatian (Čakavian) language only gets to be written as dictated by everyday, practical necessity: in legal texts, epigraphy, graffiti, colophons and rubrics of liturgical books, as well as in notes on the margins of manuscripts. [...] Latin fulfils all the functions peculiar to a literary language: it is the language of liturgy, literature and business dealings. The functions of Church Slavic and Čakavian are clearly distributed, the two idioms complementing each other [that is, Church Slavic is the language of liturgy and literature, while Čakavian functions as the language of the law - A.K.]. ${ }^{16}$

In the third quarter of the $14^{\text {th }}$ cent., Mihaljevic claims, the situation changes due to the emergence of the hybrid language (Čakavian-Church Slavic) and the transformation of the Slavic diglossia into the state of triglossia. Latin and Church Slavic are employed in liturgy; literature is the domain of Latin and the hybrid language, occasionally also Čakavian; legal texts are composed in Latin and in Čakavian. In this connection, Mihaljević observes:

This hybrid type of language is primarily used in belletristic works. From the beginning of the $15^{\text {th }}$ cent. onwards, Čakavian and Church Slavic are further joined by Kajkavian elements. [...] Church Slavic elements, usually stylistically marked, are much more widespread in the biblical context; however, the exchange of Church Slavic, Kajkavian and Čakavian features may have a purely stylistic function - aimed at avoiding repetitions and making the narrative more dynamic and interesting. ${ }^{17}$

The Baška tablet is not the only text to have spawned theoretical and classification-related questions. For instance, it remains unclear how the Čakavian and Štokavian lectionaries from the $15^{\text {th }}$ and early $16^{\text {th }}$ centuries (e.g. the Lectionary of Bernardin of Split or the Lectionary of Nikša Ranjina) should be categorized, since scholars have not considered the possibility of liturgical texts (such as lectionaries) being written in Old Croatian. Such examples draw our attention to the necessity of a more fine-grained analysis of the linguistic situation in the Middle Ages. Damjanović goes even further and asks the question (left without a definitive and unambiguous answer): are Croatian Church Slavic, the hybrid language and Old Croatian (functional) styles of the same language? If so, which one? Or are we dealing with three separate languages? ${ }^{18}$

Later in the study, we shall likewise address the issue of the stratification of the linguistic reality in the Middle Ages. However, we shall choose a somewhat different approach than our predecessors. We will attempt to analyze the linguistic situation of medieval Croatia employing the concept of three registers ${ }^{19}$ (high, middle

\footnotetext{
${ }^{16}$ M. Mihaljević, Položaj..., p. 230.

${ }^{17}$ Ibidem, p. 231.

${ }^{18}$ S. Damjanović, Jezik..., p. 24.

${ }^{19}$ Idioms whose use is conditioned by the functional situation are called registers (D. BIBER, Dimensions of register variation: a cross-linguistic comparison, Cambridge 1995, p. 7; Sociolinguistic per-
} 
and low). These registers were inherited from the old arts of rhetoric ${ }^{20}$ and poetics and were held in high esteem in the Middle Ages. Such an investigation would allow us to reach certain conclusions regarding the use of the three idioms in various functions in the speech community. Regrettably, however, no study of this sort has been undertaken so far, in spite of the long-apparent need for a fundamental investigation of medieval Croatian stylistics ${ }^{21}$.

\section{The Slavic triglossia and the three registers}

2.1. Low (colloquial) register. Today, it is difficult to say exactly how Croats expressed themselves in their everyday life in the Middle Ages. We may claim with certainty that Church Slavic was the language of books and it was only spoken to a limited extent in liturgy. Consequently, it should be assumed that the Old

spectives on register, ed. D. Biber, E. Finegan, New York 1994, p. 3-4; Ch.A. Ferguson, Dialect, register, and genre: working assumptions about conventionalization, [in:] Sociolinguistic perspectives on register..., p. 16; A. WILLI, The Languages of Aristophanes: Aspects of Linguistic Variation in Classical Attic Greek, Oxford 2003, p. 8). The term 'register' seems more correct than 'style', since "styles are not necessarily defined by a situation: it is possible to speak of the 'style' of an author or of a literary epoch" (A. Willi, The Languages..., p. 8]. Besides, the term 'register' needs to be distinguished from the term 'genre', because a "'register' is the linguistic code that is used in the creation of a text that belongs to a 'genre"'. The meaning of the linguistic term 'register' is close to the one used in music (a set of sounds that are formed in a like manner and have a common timbre). Nevertheless, many linguists use the terms 'style' and 'register' completely indiscriminately. This needs to be emphasized particularly due to the fact that a special tradition of the use of the term 'register' exists in Russian-language scholarly literature. In this connection, our conception of this term follows neither Tolstoj (for whom the term had two meanings: 1. 'corpus of texts', 2. 'list of linguistic differences', cf. Н.И. Толстой, Однос..., p. 17, 23) nor Živov (who uses the theory of register to replace the theory of diglossia, cf. В.М. Живов, Язык и культура в России XVIII в., Москва 1996). Živov (В.М. Живов, Язык..., p. 39) distinguishes the standard register (characteristic of the religious sphere and high culture) and the hybrid register (characteristic of the lay sphere and low culture). On the other hand, we discriminate among three registers (high - literary and (para)-liturgical; middle - legal and business-related; low - colloquial), relating them to the three languages (respectively: Church Slavic, the hybrid variety, and Old Croatian), used in various literary genres (respectively: Biblical books and lectionaries; statutes and documents; passing remarks on the margins of codices, inscriptions related to everyday life). ${ }^{20}$ No information on any Croatian rhetorician or any original Croatian rhetoric work from the Middle Ages has survived to our time. Rhetoric as such falls outside the scope of the present work; that being said, we need to acknowledge the fact that medieval literature generally followed the division into three registers known from ancient rhetoric. We would not like to project certain contemporary (usually more complex) classifications onto the medieval situation.

${ }^{21}$ A new study on stylistics is called for by Hercigonja, e.g. in the following fragment: One should appreciate this effort on the part of medieval Croatian writers to make their message easily, clearly and vividly interpretable, to place it at an appropriate level of literary culture, i.e. the conception of the communicatively functional, aesthetic and expressive language of their works, of new ways of communicating old topics. Future systematic research on syntax and stylistics will uncover the true image of this Glagolitic tradition of ours and reveal where its weaknesses - as well as its merits - are located. E. HerCigonjA, Nad iskonom hrvatske knjige. Rasprave o hrvatskoglagoljskom srednjovjekovlju, Zagreb 1983, p. 439. 
Croatian vernacular speech (Cr. vernakular) permeated all social classes, as the instrument of everyday interaction and the vehicle of oral/popular literature. Thus, it was realized primarily via oral communication. As far as written texts are concerned, the colloquial (or low-register) language is typical of incidental, marginal notes and of texts of a practical nature:

(1) B(ož)e! To pisa Petar pop Panceta kada staše Barbane kalonih 1447. meseca oktembra dni $16^{22}$.

(2) Se pisa Kirin žakan, Bog mu pomagaj i sa vsimi ki budu va nje peti, amen. V ime Božje amen, let gospodnjih 1359., kada te knjigi biše pisani i dopisaše se v svetom Kuzmi i Damjani v Senji. ${ }^{23}$

(3) Jebi ga vrag, amen! ${ }^{24}$

(4) Kušah kako pero piše ${ }^{25}$.

(5) Va ime Božje i svete Marije amen! Kada umri blaženi muž papa Martin na 12 dan miseca pervara ki dan slnce pomrče [...] Va toj vrime pride Isak vojevoda s Turci i porobi Vlahe i Hrvate. Tu zimu pozeboše masline i vse smokve. Pšenica pogibe i ina žita pogiboše. Malo kadi sime osta i bi do zime velik glad $[\ldots] .^{26}$

(6) Ot kače, koga uji: Prekriži krstom, omočiv ga v seru, ka je v uhi desnom, zada omaži, kadi je rana, i ne će otok moć više [...] Koga uji zmija, ali ki ti pově, r’ci da stoji s mirom, i okruži mu okolu nogi desne i vzdvigni nogu i piši ove rěči: karo karuce, karo in kruce, sanom reducet, - imreducet, sanom Imanuel Paraklitus, - omo (= homo) vivens, serpens morietur $\dagger \mathrm{v}$ ime $†$ Oca $\uparrow \mathrm{i}$ Sina $\dagger \mathrm{i}$ Duha $\dagger$ Svetoga $†$ amen $\dagger^{27}$

${ }^{22}$ Transcr. A.K. following: B. Fučić, Glagoljski natpisi, Zagreb 1982, p. 38: O God! This was written by Petar pop Panceta while he was canon in Barban in the year 1447, in the month of October, on the $16^{\text {th }}$ day.

${ }^{23}$ Colophon of the Lobkowicz Psalter, 1395: This was written by deacon Kirin, God help him, along with all those who will sing beside him, amen. In the name of God, amen, in the year of our Lord 1359, when this book was written and completed in [the church of] St. Cosmas and Damian in Senj.

${ }^{24}$ Code slave $11,14^{\text {th }}$ cent.: May the devil screw him, amen!

${ }^{25}$ HAZU archive, manuscript IVd 55, 10b, $15^{\text {th }}$ cent. Hrvatska književnost srednjega vijeka. Od XII. do XVI. stoljeća, ed. V. ŠTefanić, B. Grabar, A. Nazor, M. Pantelić, Zagreb 1969, p. 169: I was trying out the pen.

${ }^{26}$ HAZU archive, Fragm. Glag. 32/a, $15^{\text {th }}$ cent., transcr. A.K. following: V. ŠTEFANIć, Glagoljski rukopisi Jugoslavenske akademije, I dio: Uvod, Biblija, apokrifi i legende, liturgijski tekstovi, egzorcizmi i zapisi, molitvenici, teologija, crkveni govori (homiletika), pjesme, Zagreb 1969, p. 109: In the name of God and Saint Mary amen! When the blessed lord pope Martin died on the $12^{\text {th }}$ day of the month of February, on which day the sun got dimmed [...]. At that time, duke Isaak came with the Turks and subdued the Vlachs and the Croats. That winter, all olive and fig trees froze. Wheat perished and other crops perished. Grain remained barely anywhere and there was great hunger until the [next] winter. ${ }^{27}$ HAZU archive, manuscript IVd 55, $14^{\text {th }}$ cent., transcr. A.K. following: R. STROHAL, Folkloristick $i$ prilozi iz starije hrvatske knjige, ZNŽOJS 15.1, 1910, p. 127: On the snake [and the person] whom it bit: Cross yourself with the cross, having dipped it in wax which is in the right ear, smear from the back, where the wound is, and there will be no edema [...]. Who was bitten by a snake, tell him to stand calm and make a circle around his right leg, and lift the leg, and spell the following words: karo karuce, karo in kruce, sanom reducet, - imreducet, sanom Imanuel Paraklitus, - omo [= homo] vivens, serpens morietur, $\dagger$ in the name of $\dagger$ the Father $\dagger$ and Son $\dagger$ and the Holy Ghost $\dagger$ amen. 
In the above-mentioned examples, we are dealing with secular events and topics (irrespective of the invocations of God, the devil, the Holy Trinity as well as the use of the lexeme amen), which is a crucial feature of the colloquial register.

Furthermore, this register is characterized by spontaneity and the absence of restraining factors in discourse structuring (for instance, the vulgarism jebati 'screw, futuere', sera [< srati] 'earwax'); the Italian borrowings kalonih ['canon'], oktembar ['october'], mocking nickname Panceta ['bacon']).

Apart from graffiti (1), this register covers complex colophons (2), obscene expressions (3), everyday-life comments (4), expressions that recount certain (past) events in a vivid, brief and spontaneous way (5) as well as clear, concrete advice on how to heal or read spells (6). The latter type is further characterized by the presence of corrupt Latin expressions ${ }^{28}$.

In connection with the first example, it should be noted that the spontaneous language of graffiti is fundamentally distinct from the language of inscriptions, on which Fučić comments as follows: Behind each graffito - as opposed to inscriptions - is only one person. He is at the same time the initiator and the executor. A graffito is a special instance of writing, created without grand preparations; it results from the impulse of the moment and as such it is usually affectively tinged ${ }^{29}$. Still, in order to achieve a more precise classification of medieval Croatian texts, it is necessary to note that not all graffiti are written in Old Croatian - even if at times produced spontaneously, as a reaction to events or scenes presented in a church fresco. There exists a type of graffiti containing Biblical quotations or paraphrases written in Church Slavic ${ }^{30}$; cf.:

(7) Sveti tvoji vradujut! ${ }^{31}$

(8) Govori prorok se děva v črěvě32.

On the other hand, certain characteristics of the register under discussion may also be discovered in the middle register. In administrative and legal texts, for example, we find instances of direct speech that reflect communication belonging to the low register. Consider the following fragment:

(9) V tom špan poče govoriti: "Hod'te simo, sudci!" i poče ih pripravl̦ati. V tom rekoše sud-

ci: "Dobro sliši, pristave i vi plemeniti l̦udi, kih je godi totu Bog prnesal: Ča smo sudili,

\footnotetext{
${ }^{28}$ There existed certain Latin curses, e.g. M. BARAdA, Tabella plumbea Traguriensis, VAMZ 16.1, 1935, p. 11-18; P. Guberina, Tabella plumbea Sisciensis, NVj 45, 1936-1937, p. 4-23.

${ }^{29}$ B. Fučıć, Glagoljski natpisi..., p. 20.

${ }^{30}$ On this cf. J. ReInHart, Biblijski citati na hrvatskoglagoljskim natpisima, [in:] Az grišni diak Branko pridivkom Fučić, ed. T. Galović, Malinska-Rijeka-Zagreb 2011, p. 445-456.

${ }^{31}$ Transcr. A.K. following: B. FučIć, Glagoljski natpisi..., p. 195: [Let] your saints rejoice (Ps. 149:5).

${ }^{32}$ Transcr. A.K. following: B. Fučić, Glagoljski natpisi..., p. 135: The prophet says: behold, a virgin in the womb [will conceive and give birth to a son] (Is. 7:14).
} 
sudismo, i ne pačamo se va tu vodu!". V tom toga idoše Mišḷenovići i s l̦udi i s španom na suplotje Grgino i ńega bratje. I poča ih Grga ustavl̦ati s svojimi pravi pored s bratju, pravi ke imaše do našega stola, i listi kral̦a Lauša i kraḷice Marije [... . I I totu reče knez Juraj Mišḷenović: "Usrani su ti listi!"33

In poems written in the high register, e.g. in the mystery entitled The Passion of our Savior (11a-11b), we encounter a dialogue which - owing to the manner of expression and choice of words - is reminiscent of a scene of daily bargaining in the market:

(10) Tu Magd(a)l(e)na, kad dojde k spicijaru, reci:

Toj pomasti ča je cina,

da ne bude mej nami hina?

Spicijar reci:

Toj pomasti cinu stavlıu, trista dukat ja vam pravl̦u.

Magd(a)lena ogledavši pom(a)st, reci specijaru:

Ova pomast, ča mi se mni, prijatelu, vridna to ni.

Zato rec' mi sada, brajne, ča ju oćeš dat najmańe.

Specijar reci:

Odpušćam vam od te cine jedan dukat ja od mańe.

Magdalena reci:

Vele s' tanak stanovito, sam dobro znaš: vridna ni to, da pokle diš, neć' inako, kako s' rekal, budi tako.

Spicijar reci:

Prisežu vam verom na to, nis' je otil dati za to, kupili je niste drago zač je vridna vsako blago.

${ }^{33}$ Transcr. A.K. following: E. Hercigonja, Srednjovjekovna književnost..., p. 405: Then the lord [= feudal master] started speaking: "Come here, judges!" and started preparing them. Then the judges said: "Well, listen, clerks, and you, noble people, all whom God brought here: What we have judged, we have judged, and we are not meddling with this anymore!". Then the Mišljenovići went with the people and with the lord to the shelter of Grga and his brothers. And Grga together with his brothers started stopping them with their documents - documents that they had received from our curia, and letters from king Lauš and queen Marija [...]. And here [= then] king Juraj Mišljenović said: "Screw these letters!". 
Magd(a)lena pinezi dajući reci:

Na t' dukate, da t' je broju,

da na targu već ne stoju. ${ }^{34}$

2.2. Middle (moderate) register. The middle register covers the intermediate sphere of language use between the two extremes - the high and low register. It should be noted that the middle register, which constitutes a variety of Old Croatian, cannot be equated with the hybrid literary language. The surviving examples of written language (and the unrecorded spoken language) of this register were characterized by the pursuit of clarity, distinctness and integrity. Here belong legal, administrative and business-related texts. Put differently, this was the language of work and administration, spanning documents from wills through account books to military orders. We are not dealing with relaxed interaction with friends or acquaintances, but rather with public communication; its aim is, primarily, to inform or consult partners, clients, associates etc. The discourse of this register strives for formality and an official tone.

To exemplify this register, we shall, first of all, adduce fragments from three legal documents - from the famous Cyrillic Charter of Povlja (1250), a Glagolitic document from Lika (1433) and a Cyrillic will. The language of the Charter of Povlja is rather archaic, containing Church Slavicisms. On the other hand, the latter are absent from the chronologically later Glagolitic document and Cyrillic will, where the language is generally more innovative.

(11) Az Blasi, slišav od piskupa Mikule, od kneza Vlašćina, od župana Čeprńe, od sudje Luke potvrjaju i ukladaju ruku moju ${ }^{35}$.

(12) Mi Antol Ivković i Ivan Herendić, knezi vlaški, Paval vojvoda i sutci vlaški po imeni Dijan Mušković [...] i vsi dobri Vlasi svete krune kralıevstva ugarskoga v Hrvatih damo viditi

\footnotetext{
${ }^{34}$ A. Kapetanović, D. Malić, K. Štrkalj Despot, Hrvatsko srednjovjekovno pjesništvo: pjesme, plačevi i prikazanja na starohrvatskom jeziku, Zagreb 2010, p. 632-633: Here [= then] Magdalena, as she approaches the doctor [pharmacist], says: / What is the price of this ointment, / so that there is no deceit between us? / The doctor says: / On this ointment I put the price / of three hundred ducats, I'm telling you. / Taking a look at the ointment, Magdalena says to the doctor: / This ointment, it seems to me, / my friend, is not worth this much. / So, tell me, brother, / what is the least for which you are ready to give it to me. / The doctor says: / I will lower the price for you / by one ducat. / Magdalena says: / You are most stingy, / and you yourself know very well that it is not worth this much, / but if you are saying that it won't be otherwise, / let it be as you said. / The doctor says: / I swear by my faith that / I did not want to sell it - / and you did not buy it - for an excessive price, / because it is worth a fortune. / Magdalena, giving him the money, says: / Here are your ducats, let me count them for you, / so that I do not need to stand in the market anymore.

${ }^{35}$ D. Malić, Povaljska listina kao jezični spomenik, Zagreb 1988: I, Blaž, hearing from bishop Mikula [= Nicholas], prince Vlašćin, župan Čeprnja, judge Luka, confirm and lay my hand.
} 
vsim kim se dostoji pred kih obraz ta naš list pride da učinismo slobodšćinu vsemu iminju svetoga Ivana crikve v Lici na Gori ${ }^{36}$.

(13) Va ime Božje. Amen. Ja Radoslav, sin Vladisava Radišića, bude zdrav u pameti, a nemoćan u puti, nadije se odstupiti od sega svita i čińu poslidńi taštamenat ${ }^{37}$.

Among the linguistic traits typical of the moderate (middle) register, reflected in the fragments presented above, we should point out elements of official jargon such as pred obraz list prići ('bring to someone's attention'), idiomatic expressions such as učiniti slobodšćinu ('free'), zdrav u pameti, nemoćan u puti ('of sound mind but weak body'), as well as pleonasms and synonyms such as potvrjati and ukladati ruku ('confirm').

The register under discussion also covers regulations (laws and normative acts) issued by religious convents and other communities (e.g., brotherhoods). As an example of texts of this kind, we may mention the rule of the Benedictine Order (Rule of Saint Benedict), the regulations concerning the admission of nuns from Zadar into the Dominican Order (Order and Rules of the Dominican Nuns of Zadar), the rule of the Franciscan Order (Constitution of the Third Order of Franciscans) as well as a fragment from the rule of a brotherhood from Baška:

(14) Prazdnost je neprijatelj duši i zato na vrimena narejena dlžni sut bratja i rukama dělati, a na druge godine čtite svete knjige. I tako mnimo pravadno narediti 2 vrimeni: to jest jamše ot Vazma do kalendi oktobra izjutra po primi dari do terce, a čto jest potriba delajte, a po terci i po misi budite do šekste $v$ čten’ji. A po šeksti obědvajte, a po obědi vstavše počivajte vsaki vi svojej postilji tvrdim mlkom. Ako li ki hoće čisti v svojej postělji, tako čti, da druga ne budi. ${ }^{38}$

(15) I svršena molitva. Ustanet se žena ona i postavit ruke svoje meju ruke prijure i druzih sestar. I tako jima reći ona žena: "V ruke vaše priporučuju dušu i tilo moje." I ovo jima reći trikrat ona žena: "V ruke vaše...” I odgovoret vse sestre i reku: "Primi tebe Isukarst, spasitelj segaj mora, i postavi na desnu pristolja slave svoje! I mi tebe veseleći se prijimḷemo u družbu

\footnotetext{
${ }^{36}$ Transcr. A.K. following: J. VončInA, Četiri glagoljske isprave iz Like, RstI 2, 1955, p. 217-218: We, Anton Ivković and Ivan Herendić, Vlach princes, duke Paval and Vlach judges by the name of Dijan Mušković [...] and all good Vlachs of the holy crown of the Kingdom of Hungary in Croatia, bring to the attention of all whom this letter of ours shall reach that we have done everything to free the property of St. Ivan by the church in Lika na Gori.

${ }^{37}$ Transcr. A.K. following: S. Ivšić, Hrvatski ćiriliski testament Radoslavca Vladišića iz god. 1436. u prijepisu iz god. 1448, ČHP 1.1/2, 1943, p. 86: In the name of God, amen. I, Radoslav, the son of Vladislav Radišic, of sound mind but weak body, hoping to leave this world, am preparing my last will.

${ }^{38}$ Hrvatska književnost..., p. 103: Idleness is an enemy of the soul and, therefore, brothers should do manual work during the indicated time, while at other times, you should read holy books. Thus, it is necessary to distinguish two times of the day: accordingly, in the period from Easter until the beginning of October, starting at one hour [in the early morning, around 6-7 oclock] until three hours [around 9 oclock] - work, and after three hours and the mass, occupy yourselves with reading until six hours [noon]. Afterwards, dine, and following dinner, rest - each of you in your own bed, in strict silence. If someone wishes to read in their bed, let him read, but so as not to disturb others.
} 
svetu i skrušenu našu i dilnicu činimo naših molitav, mis, psalam, pisan i petja, svetoga žežinanja, pripovidanja i vsakoga dobroga i sveto[ga] našega čińenja i moḷenja duhovnoga, pojući i veseleći se u sarcah naših Gospodinu Bogu." ${ }^{39}$

(16) 38. kapitul: Ki bi govoril za stolom brez prošćen’ja kada se obedva ali vičera, tomu pokora: ne dajte mu vino piti on dan za onim jiděn'jem. Ako bi potom toga brez prošćen’ja govoril blagujući, pokora mu jedna dišiplina. Potom toga ako veće krat prěstupi tu zapovid, imij mu se ta pokora duplati. ${ }^{40}$

(17) Ot računa, kako kaštaldi imu dati. 13. [kapitul]. Budući bratija na kup, stvoret račun ot vsega ča su prijali i stratili. I vsagda brez protivu dlžni budite na račun ča Bog da da prebiva, prikazivati i ne mozite nigdare pinez brašćinskih nikomure zajati brez videnija opata i inih. ${ }^{41}$

The language of the first example (14) is characterized by linguistic archaisms and the use of multiple Church Slavicisms. In each section of the text, they serve primarily to underscore the learned environment in which the text was created, as well as to indicate that it is a copy based on an old translation. The number of Church Slavicisms in the remaining sample texts is not overly large; for example, the morphological Church Slavicism - $t$ ( $3^{\text {rd }}$ person present) in the Order and Rules of the Dominican Nuns of Zadar reflects the tendency to distinguish the text stylistically against the backdrop of the everyday Chakavain dialect. Aside from the presence of Church Slavicisms (to a lesser or greater extent), the language of this register is characterized by the influence of assorted kinds of Romance terminology (differing from text to text): terca, šeksta, kalenda, prijur, psalam, žežinjanje, dišiplina, kaštald, etc.

The middle register also comprises laws (legal acts) and charters of certain municipalities. The language in which these texts are composed features Old Croatian - or even Proto-Slavic - terminology (svidok 'witness', kmetić

\footnotetext{
${ }^{39}$ Najstariji hrvatski latinički spomenici (do sredine 15. stoljeća), ed. D. Malić, Zagreb 2004, p. 4: The prayer is finished. And that woman rises and places her hands between the hands of the prioress and of the other nuns. And that woman says the following: "Into your hands I am entrusting my soul and my body". And that woman says the following three times: "Into your hands...". And all the nuns answer her, saying: "May Jesus Christ, the savior of this sea, accept you and place you at the right hand of the throne of his glory! And, rejoicing, we are accepting you into our holy and humble community, and we are making you a fellow participant of our prayers, masses, psalms, songs and chants, holy fasting, sermons and all our good and holy deeds and spiritual prayers; we are singing and rejoicing in our Lord God in our hearts".

${ }^{40}$ Hrvatska književnost..., p. 108: Chapter 38. Who speaks at the table without asking during the time of dinner or supper, receives penance: do not allow him to drink wine during those meals on that day. And if, after that, he speaks without asking during the meal, let him receive punishment [beating]. Subsequently, if he violates this ban multiple times, let him receive double punishment.

${ }^{41}$ Transcr. A.K. following: I. MiLČEtić, Prilozi za literaturu hrvatskih glagoljskih spomenika. II. Zakon brašćine svetoga duha u Baški, Star 25, 1892, p. 146: On the report that the administrators need to file. [Chapter] 13. Having gathered, the brothers should calculate all they received and spent. And you should always indicate everything that God gave, without quarreling; and never lend the brotherhood's money without the knowledge of the abbot and others.
} 
'disenfranchised servant'), with the discourse clearly structured by the syntax (if someone..., whoever...). We shall illustrate this type of text with the following fragment of the Poljica Statute:

(18) Osud za psost. Tko bi opsovao svoga druga listo budi gdi hoćeš prez uzroka podobna, upada libar 5. [...] Tko bi opsovao kmetić svoga gospodina, dužan je da mu se jezik uriže, ali se iskupi libar $100 .{ }^{42}$

The language of some of the texts may reach the high register (the language of the Baška tablet, for example, belongs to the latter). Thus, the note on the destruction of Modruš in the Novi Missal fragment of the $15^{\text {th }}$ cent. is written in the middle register, whereas the Record of Father Martinac attains the high register (note the emotional tinge of the discourse, caused by the contemporary author's impressions on the experienced event):

(19) 1493. bi rasap grada Modruša, koga Turci porobiše, popališe, is koga pobiže častni gospodin Kristofor, biškup modruški ali karbavski i s nikoliko kanonici starešimi, ki došavši simo v Novi grad va Vinodol, i ustani se tu i učini sebi prebivanje i štolicu v crkvi svetih Filipa i Jakova apoštoli, i tih kanonici učini delnike od vsih prihodak te plovanije skupa s plovanom, ostavivši za se samo pol desetin [...] Sije pisah ja pop Petar Vidaković, plovan. ${ }^{43}$

(20) v vrěme svetago otca v Bozě pape Aleksandra Šestago i v vrěme Maksimilijana, kralja rimskago, i v vrěme kralja Laclava češkoga i ugarskago i v vrěme našega gospodina kneza Brnardina Frankapana i njega sini, kneza Matij a i kneza Krštofora i kneza Feranta, i v duhovnom našego gospodina i otca gospodina biskupa Krstopora Dubrovčanina, biskupa modruškago i krbavskago i pročaja [...] Tăgda že poběždena bisi čest krstjanska, tăgda že uhitiše bana hrvatskoga ošće živuća tăgda že ubiše bana jajačkogo. ${ }^{44}$

Numerous medieval texts - even legal ones - tend to express subjective opinions and experiences of their authors. Not uncommonly, the volitional and

\footnotetext{
${ }^{42}$ Poljički statut, ed. M. Pera, Split 1988, p. 442: Condemnation for indecent words. Whoever offends his neighbor with indecent language, regardless of the consequences, shall pay 5 libra. [...] If a servant utters indecent words towards his master, his tongue shall be cut out, or he shall pay 100 libra.

${ }^{43}$ Novi Missal fragment, 25v, $15^{\text {th }}$ cent.: 1493 saw the destruction of the town of Modruš, which was captured and burned down by the Turks. Honorable lord Kristofor, bishop of Modruš or Krbava, fled the town with some older canons. Having come here to the town of Novi in Vinodol, he settled here, taking accommodation and position in the church of the holy apostles James and Philip. He made these canons participants of all income of the parish, along with the parish priest, leaving for himself only half of the tithes. [...] This is what I myself wrote - pop Petar Vidaković, parish priest.

${ }^{44}$ Hrvatska književnost..., p. 82, 84: In the time of the Holy Father in God pope Alexander VI, and in the time of Maximilian, Roman king, and in the time of Czech and Hungarian king Laclav, and in the time of our lord prince Bernardin Frankopan and his sons - prince Matij, prince Krštofor, prince Ferant, and our spiritual lord and father bishop Krstopor Dubrovčanin, bishop of Modruš and Krbava etc. [...] At that time the Christian forces were defeated, at that time they captured the Croatian ruler alive, at that time they killed the ruler of Jajce.
} 
expressive function is visible (an emotional or provocative effect on the recipient of the message $)^{45}$.

Although the majority of the medieval literary monuments belonging to the middle register are written in the Old Croatian language (some of them with a greater or smaller number of Church Slavicisms), it is necessary to emphasize that some texts pertaining to canon law were composed in Croatian Church Slavic. For example, the Petris Miscellany (122-170b) features a number of canonical texts; some of them are written in Čakavian with Kajkavisms or Church Slavicisms, but certain others display such a level of conservatism that they have been described as follows: In general, the language of these canonical regulations seems to hark back to the Moravian period ${ }^{46}$.

\subsection{High (elevated) register}

The high register is typical of biblical/liturgical language (Vienna Folia, Split fragment of the Glagolitic missal) as well as the language of literature (Acts of Paul and Thecla), written in the prestigious Croatian Church Slavic language:

(21) Vъsuda tvoego radi eže (es)mъ vъzeli m(o)litvami ap(ostolъ) (t)voihъ ihъže pametъ čt(emъ) pom(i)lui ni ${ }^{47}$.

(22) (Měse)ca dektebra $7 \mathrm{~d}(ъ) n ъ$ Anъbro(s)iě, pěs[ni] i ap(osto)la i ev(an)ĵe(li)ě iště [na] Měkulěnъ $d(\mathrm{~b}) n ъ . M(i) s a$. Blaženoga Anbrosiě ispovidnika tvoega i ar[h]ieriě na vsaki $\mathrm{d}(\mathrm{b}) \mathrm{n}[\mathrm{b}][\ldots] .{ }^{48}$

(23) Otroci že i děvice priněse drva i seno da Těklu užgut. Jegda že izvěse ju nagu, proslzi se knez i divi se sući dobrotě jeje. Skladoše že drva i povelěše jej ljudije vzlěsti na nja. Ona že stvorši obraz Hrstov.... Ljudije že vzgnětiše ogănj. ${ }^{49}$

\footnotetext{
${ }^{45}$ What is meant here is the appearance of an emotional tone in medieval historical and legal texts, causing them to approach the status of literary works. Some examples are supplied by Damjanović (S. DAMJANović, Jezik..., p. 25), who notes that at that time, the function of effect was allotted significantly more space relative to the communicative function.

${ }^{46}$ V. ŠTEFAnić, Glagoljski rukopisi otoka Krka, Zagreb 1960, p. 369.

${ }^{47}$ V. Jagić following: J. Намм, Staroslavenska čitanka, Zagreb 1971, p. 56: For the sake of your communion, which we received, according to the prayers of your apostles, whose memory we honor, have mercy on us.

${ }^{48}$ V. ŠTefanić, Splitski odlomak glagoljskog misala starije redakcije, Slo 6/8, 1957, p. 60: In the month of December, on the $7^{\text {th }}$ day, of Ambrosius, look for songs and apostle and gospel for the day of Mikula. Service. The prayer of blessed Ambrosius, your confessor and bishop, delights us every day [...].

${ }^{49}$ Hrvatska književnost..., p. 131: Children and maidens brought wood and hay for virgin Thecla to be burnt. When they got her naked, the prince cried out in admiration of her beauty. Having put down the wood, the people ordered her to climb it. She did this in the name of Christ... The people lit the fire.
} 
We are dealing with the literary (developed and carefully crafted) language. It is quite far removed from the spontaneous, everyday use of language in the society in general. A similar kind of discourse was produced in the Middle Ages by intellectuals or people with particular aesthetic/emotional inclinations, expressed in the form of the text. Texts of the high register, particularly literary texts in the narrow sense, are characterized by richness of language, achieved through figures of speech and the adherence to the principles of ancient rhetoric and poetics. It is a premeditated, structurally complex, reflected discourse, the content of which touches upon non-trivial topics. Here, language use is a matter of tradition; the established linguistic practice is retained, stable in expressing particular kinds of content within the framework of medieval genres. Medieval Croatian literature does not know the epic; it lacks the most precious of the ancient components of literature, written in the elevated register. Serious-themed content is more appropriate for this register and it is valued higher than satire. The range of literary works of the high register could be further divided into a number of subordinate levels (depending on genre and topic).

At first, the medieval high register is associated with Croatian Church Slavic and Old Croatian (in the sphere of oral and folk literature), and later - from the $14^{\text {th }}$ cent. onwards - also with the hybrid language.

The high register also covers everyday-life texts, which, however, are not of a spontaneous nature, but pre-designed. The authors of such texts introduced Church Slavic elements into them, meant to signify the power of the language of liturgy.

(24) Zaklinam vas vrazi prokleti $\dagger$ Bogom Ocem $\dagger$ Sinom $\dagger$ Duhom Svetim i vsěmi svetimi Božjimi i Sudńim dnem, i slncem i lunu, i zvězdami nebeskim i treskom i gromom i 20 i 4-mi starci i vsu tajnu Božiju, da vi ne mozite škoditi semu rabu Božiju [...] i ni v jedinom městě ne mozite mu škoditi ni nad ńim ni v ńem se obrěsti, razvě otpadite ot ńego. V ime Oca i Sina i Duha Svetago amen! Evanjelje "iskoni bě slovo" napiši i odperi blagoslovḷenu vodu i daj tadaje běsnomu i do konca da je popje..$^{50}$

Some Glagolitic inscriptions were not created spontaneously, but rather reflected a previously thought-out structure with the use of high linguistic register - as exemplified by the rhythmical repetition of ends of words and the form [-]biše

\footnotetext{
${ }^{50}$ HAZU archive, manuscript IVd 55, $15^{\text {th }}$ cent., transcr. A.K. following: I. MiLČETIĆ, Stari glagolski recepti, egzorcizmi i zapisi, VSAK 1, 1913, p. 64: I beseech you, wretched demons, accursed by $\dagger$ God the Father + the Son + and the Holy Ghost, and by all of God's saints, by the Judgment Day, by the sun and the moon and the stars of heaven, and by lightning and thunder, and by the 24 elders and the Divine mystery, that you shall not inflict harm on this servant of God [...] and you shall not harm him anywhere or find fault in him, and you shall step back from him. In the name of the Father, the Son and the Holy Ghost, amen! Write the gospel "in the beginning was the word" and wash with holy water, and let the demoniac drink it.
} 
at the end of syntactic constructions in the Bužim inscription (Čakavian dialect of Old Croatian):

(25) Ta grad sazid(a)l iz fudumenta izibrani knez Juraj Mikuličić. U 'no vrime va vsej hrvatskoj zemḷi boḷega č(ově)ka ne biše, zač u kraḷa Matijaša u veliki počtenji biše, zač ot cara turskoga ugrskoj zeml̦i mir našal biše. I car rimski, ta ga dobrim č(ově)kom zoviše. I vs(a)ki od tih poglavit dar dal mu biše. A Hrvati ga za nenavist hercegom Ivanišem pogubiše. Ki li se oće takim č(ově)k(o)m zvati, neka takov grad iz fudumenta ima izzidati tere ima sebi tak(o). ${ }^{51}$

Some medieval texts were written both in Croatian Church Slavic and in Old Croatian, such as e.g. the eschatological liturgical song Dies irae:

(26) Quid sum miser tunc dicturus?

Quem patronum rogaturus, Cum vix justus sit securus?
Čto okan[']nik' t'gda reku Takmo o[t']cu pom[o]lu se Jegda jedva pr[a]v[e]dni sp[a] sen budet. ${ }^{52}$
Ča oću grišnik ondi reći

Ku li milost tada steći

Gdi budu dobri teško uteći? ${ }^{53}$

This song differs from oral literary and popular (secular and religious) poetry (Još pojdoh ravnim poljem / Bratja, u mladost ne ufajte / Svit se konča):

(27) Još pojdoh ravnim pol̦em, susrite me devojka, tanka boka, visoka, a na bili rumena... ${ }^{54}$

(28)... Vele oholo ja ushojah jer se smrti mlad ne bojah. Sada mladost moju zgubih, dobra děla nebog pustih, iskrnńega ja ne l̦ubih, moju dušu grihom ubih. Moja družbo, ka si bila, nut pogledaj moga tila! Moja rebra vsa ogníila, zato plači, družbo mila!

${ }^{51}$ B. Fučić, Glagoljski natpisi..., p. 112: This city was built from the foundations by prince Juraj Mikuličić. At that time, there was no better man in all of Croatian lands; he was regarded highly by king Matijaš, since he concluded the peace between the Turkish emperor and the Hungarian land. Even the Roman emperor called him a good man. And all of them brought him gifts. But the Croats killed him out of envy, aided by duke Ivaniš. Who wants to be called a man like this, let him erect a city like this from the foundations.

${ }^{52}$ Misal po zakonu Rimskoga dvora, ed. M. Pantelić, Zagreb 1971.

${ }^{53}$ A. Kapetanović, D. Malić, K. Štrkalj Despot, Hrvatsko srednjovjekovno pjesništvo..., p. 148. ${ }^{54}$ Ibidem, p. 333: I went through an even field, / a girl came across me, / slim and tall, / with pink cheeks... 


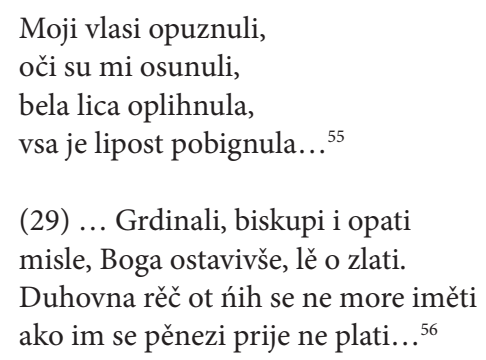

\section{Conclusion}

It follows from the above that in medieval times, there was no clear-cut division among the three languages according to function, and that the languages themselves did not constitute registers. The linguistic situation was quite diverse and dynamic.

Bearing in mind that the hybrid variety and Church Slavic did not exist as every-day (in)formal business/colloquial codes, they did not contribute to the development of the middle and low linguistic registers.

When we speak of the literature of the Middle Ages, it is necessary to consider secular oral and folk literature, which - though not committed to writing - must have existed; it is, in fact, indirectly reflected in written medieval literary works ${ }^{57}$.

In the Middle Ages, oral communication and memory occupied a more central role than in modern times. The literature that has been preserved in written literary monuments features the kind of content that was of prime importance to the clergy: copies and translations of biblical liturgical books in the Croatian Church Slavic language. The vernacular Old Croatian language is used in certain late medieval liturgical texts (lectionaries) and literature; from as early as the $14^{\text {th }}$ cent. onwards, we have Old Croatian texts preserved in which a high level of expression is achieved (e.g. Šibenska molitva / Šibenik prayer, Vatikanski hrvatski molitvenik / Vatican Croatian Prayer Book). Here, Church Slavicisms are, more or less, the markers of the high register. Accordingly, the Old Croatian language possessed all three registers (high, middle, low). The bulk of Croatian linguistic culture of the Middle Ages was characterized by the use of the Old Croatian vernacular, although, in view of the number of extant liturgical and (usually religious)

\footnotetext{
${ }^{55}$ Ibidem, p. 17-30: ... I went very boldly, / since, being young, I did not fear death. / Now I have lost my youth, / left my good deeds, / I did not love my neighbor, / I killed my soul with sin. / My former friends, / look at my body! / My ribs are all rotten, / so cry, my dear friends! / My hair has all fallen out, / my eyes have collapsed, / my white cheeks have grown thin, / all my beauty is gone...

${ }^{56}$ Ibidem, p. 328:...Cardinals, bishops and abbots, / having abandoned God, they only think about gold. / One cannot get a spiritual word out of them / unless one pays them first...

${ }^{57}$ M. BošKović-Stulli, Usmena književnost, [in:] M. BošKović-Stulli, D. Zečević, Usmena i pučka književnost, Zagreb 1978, p. 68-152.
} 
literary texts - meticulously copied and protected by the clergy - one usually gets the impression that this linguistic milieu was dominated by Church Slavic.

In the above examples, we have shown that even graffiti (the type of text closest to the low register) could be written in the Church Slavic language under certain circumstances (biblical quotations/paraphrases). The same applies to some texts of canonical law (non-liturgical and non- belletristic texts of the middle register). In literary and legal texts (high and middle register), it is possible to find expressions that originate in the low register or are constructed according to this register's linguistic usage (as exemplified by the document from Lika or the communicative informality of the dialogue in the Muke Spasitelja našega / Passion of our Savior). Besides, certain Old Croatian legal texts display an evident increase of the volitional and expressive function of the text, as well as of the careful choice of phrasing (ars dictandi); from the point of view of a modern scholar, this renders such texts closer to the high register of literature. We have even adduced an example of a liturgical text translated into both Church Slavic and Old Croatian (Dies irae); such cases make it clear that certain variants of literary texts composed in the vernacular language were specially stylized.

The general analysis indicates that already in the Middle Ages, the Old Croatian language - with its variegated dialectal base - possessed all three registers (high, middle and low). Consequently, the view that the creation and development of the early Croatian literary language constituted a gradual transformation of Church Slavic should be finally abandoned.

Translated by Marek Majer

\section{Bibliography}

Barada M., Tabella plumbea Traguriensis, "Vjesnik Arheološkog muzeja u Zagrebu” 16.1, 1935, p. 11-18.

Biber D., Dimensions of register variation: a cross-linguistic comparison, Cambridge 1995.

BošKović-Stulli M., Usmena književnost, [in:] M. BošKović-STulli, D. ZečEvić, Usmena i pučka književnost, Zagreb 1978.

Chjutl'-Fol'ter G., Diglossija v Drevnej Rusi, “Wiener Slavistisches Jahrbuch” 24, 1978, p. 108-123.

Curtius E.R., Evropska književnost i latinsko srednjovjekovlje, trans. S. Markuš, ed. T. LAdan, Zagreb 1971.

Damjanović S., Jezik hrvatskih glagoljaša, Zagreb 2008.

Ferguson Ch.A., Diglossia, "Word" 15, 1959, p. 325-340.

FERguson Ch.A., Dialect, register, and genre: Working assumptions about conventionalization, [in:] Sociolinguistic perspectives on register, ed. D. Biber, E. Finegan, New York 1994, p. 15-30.

Fernández M., Diglossia. A Comprehensive Bibliography 1960-1999 and supplements, AmsterdamPhiladelphia 1993. 
Fishman J.A., Bilingualism with and withouth diglossia, diglossia with and without bilingualism, "Journal of Social Issues" 23.2, 1993, p. 29-38.

Fučić B., Glagoljski natpisi, Zagreb 1982.

Guberina P., Tabella plumbea Sisciensis, “Nastavni vjesnik” 45, 1936/1937, p. 4-23.

Намм J., Staroslavenska čitanka, Zagreb 1971.

Hercigonja E., Srednjovjekovna književnost, Zagreb 1975.

HerCigonja E., Nad iskonom hrvatske knjige. Rasprave o hrvatskoglagoljskom srednjovjekovlju, Zagreb 1983.

Hrvatska književnost srednjega vijeka. Od XII. do XVI. stoljeća, ed. V. ŠTEFAnIć, B. Grabar, A. Nazor, M. Pantelić, Zagreb 1969.

Ivšıć S., Hrvatski ćiriliski testament Radoslavca Vladišića iz god. 1436. u prijepisu iz god. 1448, "Časopis za hrvatsku poviest" 1.1/2, 1943, p. 83-87.

Kapetanović A., Malić D., Štrkalj Despot K., Hrvatsko srednjovjekovno pjesništvo: pjesme, plačevi i prikazanja na starohrvatskom jeziku, Zagreb 2010.

Kapetanović A., Reflections of Church Slavonic-Croatian diglossia on the Baška tablet: a new contribution concerning its language and linguistic layers, "Zeitschrift für Slawistik" 60.3, 2015, p. 335-365.

KatičIĆ R., Hrvatski jezik, Zagreb 2013.

Malıć D., Povaljska listina kao jezični spomenik, Zagreb 1988.

Minaljević M., Položaj crkvenoslavenskoga jezika u hrvatskoj srednjovjekovnoj kulturi, [in:] Zbornik na trudovi od Megjunarodniot naučen sobir [Ohrid, 4-7.11.2010], ed. I. Velev, A. GIREvski, L. Makarijoska, I. Piperkoski, K. Mokrova, Skopje 2011, p. 229-238.

MilčEtić I., Prilozi za literaturu hrvatskih glagoljskih spomenika. II. Zakon brašćine svetoga duha u Baški, "Starine, na sviet izdaje Jugoslavenska akademija znanosti i umjetnosti, Zagreb" 25, 1892, p. 138-151.

MiLČetić I., Stari glagolski recepti, egzorcizmi i zapisi, "Vjesnik Staroslavenske akademije u Krku" 1, 1913, p. 61-69.

Misal po zakonu Rimskoga dvora, ed. M. Pantelić, Zagreb 1971.

Najstariji hrvatski latinički spomenici (do sredine 15. stoljeća), ed. D. Malić, Zagreb 2004.

NAzor A., Jezični kriteriji pri određivanju donje granice crkvenoslavenskog jezika u hrvatskoglagoljskim tekstovima (Prilog diskusiji o problemima crkvenoslavenskog thesaurusa), "Slovo" 13, 1983, p. 68-86.

Poljički statut, ed. M. Pera, Split 1988.

ReInhart J., Biblijski citati na hrvatskoglagoljskim natpisima, [in:] Az grišni diak Branko pridivkom Fučić, ed. T. GALović, Malinska-Rijeka-Zagreb 2011, p. 445-456.

Seemann K.-D., Die 'Diglossie' und die Systeme der sprachlichen Kommunikation im alten Russland, [in:] Slavistische Studien zum IX. Internationalen Slavistenkongress in Kiev, Köln-Wien 1983, p. 553-561.

Sociolinguistic perspectives on register, ed. D. Biber, E. Finegan, New York 1994.

Stamać A., 'Baščanska ploča' kao književno djelo, “Croatica” 26/28, 1987, p. 17-27.

STIPIšIć J., Pomoćne povijesne znanosti u teoriji i praksi, Zagreb 1972.

Strohal R., Folkloristički prilozi iz starije hrvatske knjige, "Zbornik za narodni život i običaje Južnih Slavena" 15.1, 1910, p. 120-132. 
ŠAPIR M.I., Teorija "cerkovnoslavjansko-russkoj diglossii" i ee storonniki. Po povodu knigi B.A. Uspenskogo "Istorija russkogo literaturnogo jazyka (XI-XVIII vv.)", "Russian linguistics" 13.3, 1989, p. 271-309.

ŠTEFAnIĆ V., Splitski odlomak glagoljskog misala starije redakcije, “Slovo” 6/8, 1957, p. 54-133.

ŠTEFAnIĆ V., Glagoljski rukopisi otoka Krka, Zagreb 1960.

ŠTefanić V., Glagoljski rukopisi Jugoslavenske akademije. I dio: Uvod, Biblija, apokrifi i legende, liturgijski tekstovi, egzorcizmi i zapisi, molitvenici, teologija, crkveni govori (homiletika), pjesme, Zagreb 1969.

Tномаs G., The Role of Diglossia in the Development of the Slavonic Literary Languages, "Slavistična revija" 37, 1989, p. 273-282.

Tolstoj N.I., Odnos starog srpskog knjiškog jezika prema starom slovenskom jeziku (U vezi sa razvojem žanrova u staroj srpskoj književnosti), "Naučni sastanak slavista u Vukove dane" 8.1, 1982, p. $15-25$.

Uluchanov I.S., O jazyke Drevnej Rusi, Moskva 1972.

UsPenskij V.A., Diglossija i dvujazyčie v istorii russkogo literaturnogo jazyka, "International Journal of Slavic Linguistics and Poetics" 27, 1983, p. 81-126.

VonČInA J., Četiri glagoljske isprave iz Like, "Radovi Staroslavenskog instituta” 2, 1955, p. 213-230.

Worth D.S., On diglossia in Medieval Russia, "Die Welt der Slaven” 23, 1978, p. 371-393.

Willi A., The Languages of Aristophanes: Aspects of Linguistic Variation in Classical Attic Greek, Oxford 2003.

Žıvov V.M., Jazyk i kul'tura v Rossii XVIII v., Moskva 1996.

\begin{abstract}
The linguistic situation in medieval Croatia was fairly dynamic. The present article discusses the stratification of linguistic culture in the Middle Ages as regards its division into the three registers (high, middle, low) inherited from ancient rhetoric and poetry and received in the Middle Ages. We conclude that there was no strict division among the three languages according to function in the Middle Ages, and that the languages themselves did not constitute styles or registers. The Old Croatian language possessed all three registers (high, middle, low) already in the Middle Ages. However, the hybrid Čakavian-Church Slavic variety as well as the Croatian redaction of Church Slavic were not used as everyday (in)formal business/colloquial codes, so that they did not develop a middle and low linguistic register.
\end{abstract}

Keywords: register, diglossia, triglossia, medieval Croatia, Old Croatian, Croatian Church Slavic

\title{
Amir Kapetanović
}

Institute of Croatian Language and Linguistics Republike Austrije 16, 10000 Zagreb, Croatia akapetan@ihjj.hr 